The Fifth Scientific Conference of Obour Institutes

"Engineering and Informatics for Sustainable Smart Organizations "

\title{
The Effect of Digital Transformation on the Smart Educational Services of Egyptian Universities
}

\author{
Dr. Mohamed Seyam ${ }^{1}$, Dr. Haitham Elbasuony ${ }^{2 .}$ Dr. Saeid Hemeda ${ }^{3}$ \\ ${ }^{1}$ Lecturer at Al-Obour Higher Institute for Management and Informatics \\ drmohamedsyam@oi.edu.eg \\ ${ }^{2}$ Lecturers at Al-Obour Higher Institute for Management and Informatics \\ helbasuony@oi.edu.eg \\ ${ }^{3}$ Lecturers at Al-Obour Higher Institute for Management and Informatics \\ Saiedhemeda@oi.edu.eg
}

\begin{abstract}
This research aims to show the impact of digital transformation on the performance of higher education institutions in Egypt, especially after the recent waves that led to digital transformation around the world and its very important impact on the graduates of these universities. The world in general and universities in particular, such as Covid-19. This study was applied to a sample of faculty members and students in Egyptian universities, where it included 68 members of academics and 46 members of students in order to know the impact of digital transformation in higher education institutions. This study concluded that the use of the Internet as a tool for digital transformation affects business performance in higher education institutions, digital technologies affect university performance, and finally digital transformation leads to accurate data analytics, which helps in the rational decision-making process.
\end{abstract}

Keywords: Digital Transformation; Higher Education; Egyptian Universities; Smart Educational

\section{Introduction}

In recent decades, universities have been experiencing a set of important changes, induced by technological and social trends towards digitalization. Like all revolutions, the digital involves an intense readjustment in all sectors, from the production and energy chain, to banking.

Currently, the adoption of technologies by universities is related to a paradigm shift, where technology is conceived as a complex and interconnected environment that enables digital learning [4].
In this way, the interest is focused more on the students than on the technology itself, in addition to the learning experiences it allows.

In this context, digitalization is a necessity in higher education institutions (HEIs) capable of attracting more and better students, improving the experience of courses, teaching materials, and the training process in general [5,6]. It also allows monitoring in order to detect training obstacles and reduce the risk of dropping out of school. However, reluctance to understand and take advantage of the opportunities to move towards this digital environment persists. 


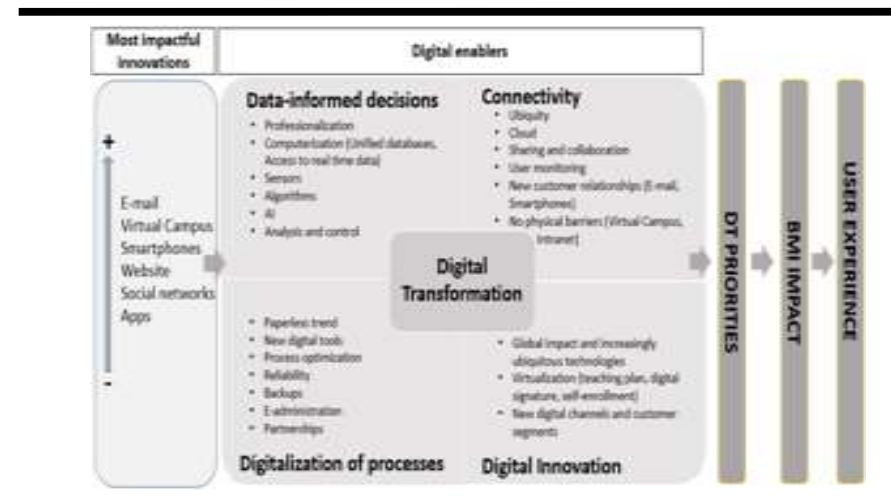

Figure (1) Digital transformation for Higher Educations

Figure 1 illustrates the elements of digital transformation in universities in general, in order to achieve sustainability in higher education institutions.

\section{Research problem:}

Accordingly, does digital transformation affect the performance of higher education institutions in Egypt, which means that there is a state of ambiguity regarding the role of digital transformation in achieving a better quality of higher education. The research problem can be formulated in the following research questions:

Are the requirements for digital transformation sufficiently present in higher education institutions?

Do digital technologies affect the performance of higher education institutions?

Do you have use of cloud computing technology?

Digital transformation provides business models and strategies?

\section{Research aims:}

In light of the research questions, the main objectives of the research are:

Discover the requirements of digital transformation in higher education institutions.

Learn about digital technologies in higher education institutions.

Knowing the extent to which cloud computing technology can be used.

Demonstrate whether digital transformation is affecting business strategies.

\section{Research Hypothesis:}

1. Ho1: There are no requirements for digital transformation in higher education institutions.

2. Ho2: Digital technologies do not affect the performance of higher education institutions.

3. Ho3: The use of cloud computing technology does not affect the performance of higher education institutions.

4. Ho4: Digital transformation does not provide business models and strategies for higher education institutions.

\section{Lecturers Review:}

(Popova et al., 2020) The article discusses the economic and organizational aspects of the university digital transformation in the transition to Smart University. It is proposed to understand digital transformation as one of the university digital maturity levels. Digital maturity levels such as initial digitalization and digital manageability are also highlighted. The university digital transformation objects (data, university processes, user interfaces and people) are defined. The management system importance in the process of university digital transformation is indicated. The article also offers conceptual models for managing the university digital transformation in the form of managed Markov chains that take into account the educational environment specifics. The transformation processes modeling is carried out by the iterative optimization method. It is also considered the technological process of managing the university transformation based on digital technologies. The developed and proposed models and methods of decision-making in the university digital transformation management system take into consideration the management process versatility, as well as the degree of its uncertainty. The proposed models can be applied in the project offices activities to manage the university digital transformation and the transition to Smart education concept. The experience of creating an organizational infrastructure for digital transformation is considered on the example of Russian universities.

(Gafurov et al., 2020) Digitalization and transition to a new technological structure bring humanity to another level of development. The changing technological structures, industry and society progress, enhance the importance of improving the university development model. The existing management system and infrastructure in universities are often outdated and unable to ensure their competitive and adequate functioning. Hence, the need to improve the processes of using the university infrastructure through digital technology, The composition and range of the resources should also be reviewed and supplemented with new components, The purpose of this work is to reveal the principles and requirements for improving the university infrastructure using digital technology. The methodology is based on modeling the university management system, with the concept of infrastructure logic as a core, meant to include new elements in the university management infrastructure: university stakeholders, cultural values, investments and translation, The management model transformation implies a transition from structural to infrastructural approach, from infrastructure management to managing the infrastructure logic. The digital network platform incorporating the information on all the infrastructure facilities, their status, will provide effective user access management to each university resource.

(Rof et al., 2020) The higher education sector is in the eye of the hurricane of the digital revolution, immersed as it is in an ongoing digital transformation (DT) process that is expected to result in significant changes in the current business model. Despite the relevance of this transformation, little remains known about how the business model is innovated (BMI), due to the impact of digital transformation in the context of higher education institutions (HEI). This research explores the impact of DT on the HEI business model, through analyzing the case of a 
traditional university, conceived non-digitally. The results present the HEI understanding of DT, the main tensions arising from the DT process for each of the business model dimensions, and the anticipated solutions for solving these tensions. Additionally, the results uncover the existence of an emergent (non-formalized) envisioned business model, which is a visualization of how the current business model is expected to be innovated, due to the impact of DT. The main originality of this paper is in addressing a research gap at the intersection of DT and BMI in the HEI context.

(Abad et al., 2020) Digital transformation in the education sector has implied the involvement of sustainable management, in order to adapt to the changes imposed by new technologies. Trends in global research on this topic have been analyzed and studied, during the 1986-2019 period. To achieve this purpose, a bibliometric study of 1590 articles from the Scopus database has been applied. The results provided data on the scientific productivity of authors, journals, institutions, and countries that contribute to the development of this research area. The evidence reveals an exponential trend, with special interest in the last five years. The main categories are Social Sciences and Environmental Science. The most productive journal is Sustainability. The author with more articles is Mulder, from The Hague University of Applied Sciences. The most productive institution is Delft University of Technology. The USA is the country with the most academic publications and international collaborations in its studies. The main keywords used in the articles are "sustainability", "sustainable development", "higher education", "innovation", "technology", "environmental technology", "technological development", and "environmental management". Global research has followed a growing trend, with optimal publication levels in recent years.

\section{Methodology \& Result :}

Descriptive statistics for the demographic variables of the study sample

The descriptive statistics of the demographic variables related to the first part of the survey list include (occupational, academic qualification, years of experience), in the tables (1) they can be presented as follows: the following:

Table (1) Frequency distribution of respondents based on demographic variables

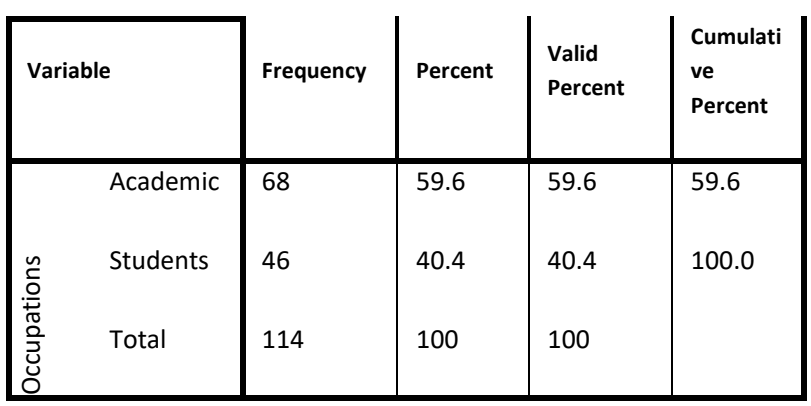

\begin{tabular}{|c|c|c|c|c|c|}
\hline \multirow{6}{*}{ 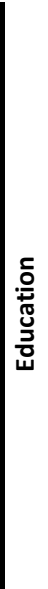 } & $\begin{array}{l}\text { Pre- } \\
\text { university }\end{array}$ & 1 & .9 & .9 & .9 \\
\hline & $\begin{array}{l}\text { Bachelor' } \\
\text { s degree }\end{array}$ & 73 & 64.0 & 64.0 & 64.9 \\
\hline & $\begin{array}{l}\text { Diploma } \\
\text { degree }\end{array}$ & 22 & 19.3 & 19.3 & 84.2 \\
\hline & $\begin{array}{l}\text { Master's } \\
\text { degree }\end{array}$ & 13 & 11.4 & 11.4 & 95.6 \\
\hline & PhD & 5 & 4.4 & 4.4 & 100.0 \\
\hline & Total & 114 & 100.0 & 100.0 & \\
\hline \multirow{5}{*}{ 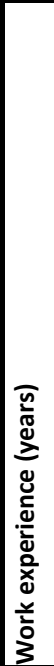 } & $\begin{array}{l}\text { Less than } \\
5 \text { years }\end{array}$ & 26 & 22.8 & 22.8 & 22.8 \\
\hline & $\begin{array}{l}\text { From }{ }^{\circ} \\
\text { years to } \\
10 \text { years }\end{array}$ & 43 & 37.7 & 37.7 & 60.5 \\
\hline & $\begin{array}{l}\text { From } 10 \\
\text { years to } \\
15 \text { years }\end{array}$ & 32 & 28.1 & 28.1 & 88.6 \\
\hline & $\begin{array}{l}\text { More } \\
\text { than } 15 \\
\text { years }\end{array}$ & 13 & 11.4 & 11.4 & 100.0 \\
\hline & Total & 114 & 100.0 & 100.0 & \\
\hline
\end{tabular}

It is clear from the table that the distribution of the study sample items according to their profession indicates that the first category is the academic with a percentage of (59.6\%), followed by students in the second place with a percentage $(40.4 \%)$ of the total vocabulary of the study sample, and it is also clear that the distribution of the study sample items according to academic qualification , indicates that the first rank is the category of those with higher qualifications, which is the largest category. with a percentage $(64 \%)$, followed by those with a postgraduate diploma with a percentage of $(19.3 \%)$, then in the third place came the category of masters holders with a percentage of $(11.4 \%)$, and the fourth category came in the category of doctoral holders with a percentage of (4.4\%), and the last category was the recipients On average qualification $(0.9 \%)$ of the total vocabulary of the study sample. It is also clear that the distribution of the study sample elements according to years of experience indicates that the experience category (from 5 to less than 10 years) is the first category with a percentage of (37.7\%), and the second category (from 10 to less than 15 years with a percentage of $(28.1 \%)$ ). And the third category (less than 5 years) by (22.8\%), and finally the category (from 15 years and over) with (11.4\%) of the total items of the study sample. 


\section{Hypotheses Testing:}

To test the data normality concerning the variables under study, the significance levels of normality test were higher than $5 \%$ error, which means that data are normal.

Table (2) The results of the t-test at the level of significance (0.5) for first hypothesis

\begin{tabular}{|c|c|c|c|c|c|c|}
\hline \multirow{3}{*}{ Variables } & \multicolumn{6}{|c|}{ Test Value $=0$} \\
\hline & \multirow[b]{2}{*}{$\mathrm{t}$} & \multirow[b]{2}{*}{$d f$} & \multirow{2}{*}{$\begin{array}{l}\text { Sig. } \\
\text { tailed }\end{array}$} & \multirow{2}{*}{$\begin{array}{l}\text { Mean } \\
\text { Difference }\end{array}$} & \multicolumn{2}{|c|}{$\begin{array}{l}95 \% \text { Confidence } \\
\text { Interval of the } \\
\text { Difference }\end{array}$} \\
\hline & & & & & Lower & Upper \\
\hline $\begin{array}{l}\text { 1. Do you have an } \\
\text { environment } \\
\text { conducive to digital } \\
\text { transformation? }\end{array}$ & 60.91 & $\begin{array}{l}11 \\
3\end{array}$ & .000 & 4.228 & 4.09 & 4.37 \\
\hline $\begin{array}{l}\text { 2. Internet use } \\
\text { affects business } \\
\text { performance at the } \\
\text { university. }\end{array}$ & 89.03 & $\begin{array}{l}11 \\
3\end{array}$ & .000 & 4.570 & 4.47 & 4.67 \\
\hline $\begin{array}{l}\text { 3. Digital } \\
\text { technologies affect } \\
\text { university } \\
\text { performance }\end{array}$ & 88.37 & $\begin{array}{l}11 \\
3\end{array}$ & .000 & 4.553 & 4.45 & 4.65 \\
\hline $\begin{array}{l}\text { 4. Do you have } \\
\text { tangible smart } \\
\text { devices? }\end{array}$ & 67.34 & $\begin{array}{l}11 \\
3\end{array}$ & .000 & 4.447 & 4.32 & 4.58 \\
\hline $\begin{array}{l}\text { 5. Do you have a } \\
\text { phone app? }\end{array}$ & 28.69 & $\begin{array}{l}11 \\
3\end{array}$ & .000 & 3.202 & 2.98 & 3.42 \\
\hline $\begin{array}{l}\text { 6. Do you have } \\
\text { multiple systems? }\end{array}$ & 43.30 & $\begin{array}{l}11 \\
3\end{array}$ & .000 & 3.939 & 3.76 & 4.12 \\
\hline $\begin{array}{l}\text { 7. Is cloud } \\
\text { computing } \\
\text { technology used? }\end{array}$ & $\begin{array}{l}57.87 \\
0\end{array}$ & $\begin{array}{l}11 \\
3\end{array}$ & .000 & 4.254 & 4.11 & 4.40 \\
\hline $\begin{array}{l}\text { 8. Do you have } \\
\text { educational digital } \\
\text { resources? }\end{array}$ & $\begin{array}{l}66.47 \\
4\end{array}$ & $\begin{array}{l}11 \\
3\end{array}$ & .000 & 4.298 & 4.17 & 4.43 \\
\hline $\begin{array}{l}\text { 9. Do you have a } \\
\text { hypothetical } \\
\text { parameter? }\end{array}$ & $\begin{array}{l}57.43 \\
6\end{array}$ & $\begin{array}{l}11 \\
3\end{array}$ & .000 & 4.219 & 4.07 & 4.36 \\
\hline $\begin{array}{l}\text { 10. Digital } \\
\text { transformation } \\
\text { supports new } \\
\text { technologies and } \\
\text { ideas. }\end{array}$ & $\begin{array}{l}69.39 \\
5\end{array}$ & $\begin{array}{l}11 \\
3\end{array}$ & .000 & 4.281 & 4.16 & 4.40 \\
\hline $\begin{array}{l}\text { 11. Digital } \\
\text { transformation } \\
\text { improves customer } \\
\text { experience. }\end{array}$ & $\begin{array}{l}78.50 \\
6\end{array}$ & $\begin{array}{l}11 \\
3\end{array}$ & .000 & 4.509 & 4.39 & 4.62 \\
\hline $\begin{array}{l}\text { 12. Digital } \\
\text { transformation } \\
\text { leads to data } \\
\text { analytics. }\end{array}$ & $\begin{array}{l}82.48 \\
4\end{array}$ & $\begin{array}{l}11 \\
3\end{array}$ & .000 & 4.509 & 4.40 & 4.62 \\
\hline
\end{tabular}

\begin{tabular}{|l|l|l|l|l|l|l}
$\begin{array}{l}\text { 13. Digital } \\
\text { transformation } \\
\text { provides business } \\
\text { models and } \\
\text { strategies. }\end{array}$ & 78.96 & $\begin{array}{l}11 \\
3\end{array}$ & .000 & 4.623 & 4.52 & 4.73 \\
$\begin{array}{l}\text { 14. Smart } \\
\text { governance } \\
\text { supports the digital } \\
\text { transformation } \\
\text { system. }\end{array}$ & 94.79 & $\begin{array}{l}11 \\
3\end{array}$ & .000 & 4.377 & 4.24 & 4.51 \\
\hline
\end{tabular}

The statistical data of the first hypothesis test as shown in Table 6 refer to the following results:

The null hypothesis test $\mathrm{H} 0$ at the level of significance 0.05 using the One Sample T test for one sample, the tabular value T at 113 degrees of freedom is 1.697 , and since it is less than the calculated T-statistic value as shown by the outputs of the SPSS program, and by comparing the results, we find that the value of the t-statistic for the expression, (Internet use affects business performance at the university, Digital technologies affect university performance, Digital transformation provides business models and strategies, $(2,3,13)$ are relatively high, reaching $(89,038,88.377,88.967)$, respectively.

\section{Recommendation}

The recommendations formulated to improve the university infrastructure using digital technology will make higher education more effective.

\section{References}

[1] Abad-Segura, E., González-Zamar, M. D., InfanteMoro, J. C., \& Ruipérez García, G. (2020). Sustainable management of digital transformation in higher education: Global research trends. Sustainability, 12(5), 2107.

[2] Abdulrahim, H., \& Mabrouk, F. (2020). COVID-19 and the Digital Transformation of Saudi Higher Education. Asian Journal of Distance Education, 15(1), 291-306.

[3] Gafurov, I. R., Safiullin, M. R., Akhmetshin, E. M., Gapsalamov, A. R., \& Vasilev, V. L. (2020). Change of the Higher Education Paradigm in the Context of Digital Transformation: From Resource Management to Access Control. International Journal of Higher Education, 9(3), 71-85.

[4] García-Peñalvo, F. J. (2021). Avoiding the dark side of digital transformation in teaching. An institutional reference framework for eLearning in higher education. Sustainability, 13(4), 2023.

[5] García-Peñalvo, F. J. (2021). Avoiding the dark side of digital transformation in teaching. An institutional reference framework for eLearning in higher education. Sustainability, 13(4), 2023.

[6] Monteiro, A., \& Leite, C. (2021). Digital literacies in higher education: skills, uses, opportunities and 
obstacles to digital transformation. Revista de Educación a Distancia (RED), 21(65).

[7] Popova, T. N., Mitrofanova, Y. S., Ivanova, O. A., \& Vereshchak, S. B. (2020). Economic and organizational aspects of university digital transformation. In Smart Education and e-Learning 2020 (pp. 371-381). Springer, Singapore.

[8] Rof, A., Bikfalvi, A., \& Marquès, P. (2020). Digital transformation for business model innovation in higher education: Overcoming the tensions. Sustainability, 12(12), 4980.

[9] Yureva, O. V., Burganova, L. A., Kukushkina, O. Y., Syradoev, D. V., \& Myagkov, G. P. (2020). Digital transformation and its risks in higher education: Students' and teachers' attitude.

[10] Mohamed Hashim, M. A., Tlemsani, I., \& Matthews, R. (2021). Higher education strategy in digital transformation. Education and Information Technologies, 1-25.

Goulart, V. G., Liboni, L. B., \& Cezarino, L. O. (2021). Balancing skills in the digital transformation era: The future of jobs and the role of higher education. Industry and Higher Education, 09504222211029796

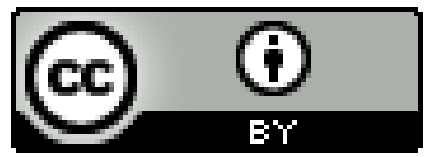

